\title{
ОСОБЛИВОСТІ МОРФОГЕНЕЗУ ЯЗИКА ЩУРІВ ПРИ ПОРУШЕННІ ВОДНО-ЕЛЕКТРОЛІТНОГО БАЛАНСУ ОРГАНІЗМУ
}

\author{
๑Л. М. Давидова, Г. Ф. Ткач, С. М. Герман, А. М. Буштрук, О. С. Максимова \\ Сумський державний університет
}

РЕЗЮМЕ. Дегідратація є однією з причин функціональних захворювань слизової оболонки порожнини рота. Вивчення змін язика на клітинному та тканинному рівнях за умов впливу гіпертонічної дегідратації організму сприятиме отриманню нових знань для наукового обґрунтування цілеспрямованої розробки заходів профілактики та коректної медикаментозної терапії порушень язика у людини і тварин.

Метою дослідження було вивчити морфологічні особливості язика щурів за умов впливу внутрішньоклітинної дегідратації організму. Для експерименту було використано 20 білих лабораторних щурів.

Матеріал і методи. Дослідження препаратів проводили з використанням світлового мікроскопа Olympus ВН-2 (Японія), електронного трансмісійного мікроскопа «ПЭМ-100м» (Суми, Україна) та растрового електронного мікроскопа «РЭМ-106» (Суми, Україна).

Результати. Встановлено, що вплив легкого ступеня клітинного зневоднення призводить до порушення упорядкованого розподілу клітин епітелію слизової оболонки язика. Епітеліоцити базального та шипуватого шарів зменшуються у розмірах, втрачаючи між собою контакти. Збільшуються міжклітинні проміжки. Відбувається передчасне руйнування зернистих клітин та набряк власної пластинки. Товщина епітелію збільшується на 3,86 \% ( $p=0,0791)$, а власної пластинки - на 6,46 \% ( $p=0,2094)$. Пучки міофібрил локально стоншуються, місцями, втрачають паралельне розташування, набувають хвилястого напрямку за рахунок набряку сполучнотканинних прошарків. Ширина ендомізіюта перимізію збільшується на 5,37\% (p=0,6772) та 6,23\% (p=0,6057). Судини мікроциркуляторного русла стають повнокровними, стінки набряклими, а їх просвіти розширеними.

КЛючОВІ СЛОВА: слизова оболонка язика; внутрішньоклітинна дегідратація; ультраструктура.

Зв'язок роботи з науковими програмами, планами, темами. Робота $\epsilon$ складовою частиною науководослідної теми кафедри нормальної анатомії людини Сумського державного університету «Закономірності вікових та конституціональних морфологічних перетворень внутрішніх органів і кісткової системи за умов впливу ендо- та екзогенних чинників і шляхи їх корекції» (№ держ. реєстрації 0113U001347) та фрагментом НДР МОН України «Морфофункціональний моніторинг стану органів і систем організму за умов порушення гомеостазу» (№ держ. реєстрації 0109U008714).

Вступ. Порушення водного обміну (дисгідрії) можуть проявлятися дегідратацією (зневодненням) або гіпергідратацією (надлишоком води в організмі) [1]. У клініці найчастіше зустрічаються зі зневодненням. Організм людини високочутливий до дегідратації і значно більш стійкий до гіпергідратації. Ці розлади нерозривно пов'язані з дією законів підтримання нормального $\mathrm{pH}$, зі змінами осмолярності рідин організму, обміну натрію, калію, хлору, бікарбонату, кислотно-лужного балансу крові, що спонукає називати їх водно-електролітними порушеннями. Осмотична концентрація інтерстиціальної рідини визначається вмістом у ній іонів натрію, залежно від концентрації якого виділяють наступні види дегідратації: ізотонічну (натрій в нормі), гіпотонічну (натрій нижче норми) та гіпертонічну (натрій вище норми). При гіпертонічній дегідратації втрати води перевищують втрати натрію (натрій плазми більше 150 ммоль/л) [2]. Оскільки при підвищенні концентрації натрію у плазмі крові відбувається підвищення ії осмолярності, внутрішньоклітинна рідина починає переходити у судинне русло, формується клітинний ексикоз (внутрішньоклітинна дегідратація) $[3,4]$.
Дегідратація $\epsilon$ однією з причин функціональної ксеростомії - зміни слизової оболонки порожнини рота $[5,6]$. Клінічними симптомами часткової або повної ксеростомії $\epsilon$ сухість у роті, у тяжких випадках порушені функції мови, ковтання, жування, смакова чутливість. У хворих у ротовій порожнині відзначається пекучий біль, слизова оболонка має яскраво-червоний або матовий колір, місцями вкрита липким густим слизом. Спостерігаються тріщини язика та атрофія його сосочків $[7,8]$.

Водночас, невисвітленими залишаються морфологічні особливості язика при гіпертонічній дегідратації, тому дослідження язика на клітинному та тканинному рівнях сприятиме розкриттю особливостей будови язика в умовах внутрішньоклітинної дегідратації організму та отриманню нових знань для наукового обґрунтування цілеспрямованої розробки заходів профілактики та коректної медикаментозної терапії порушень язика у людини і тварин.

Мета дослідження - вивчити морфологічні особливості язика щурів за умов впливу гіпертонічної дегідратації організму. 
Огляди літератури, оригінальні дослідження, погляд на проблему

Матеріал і методи дослідження. Для дослідження було використано 20 білих лабораторних щурів-самців зрілого віку. Тварин поділили на експериментальну та контрольну серії (по 10 щурів відповідно). Щурам експериментальної серії моделювали легкий ступінь внутрішньоклітинної дегідратації за моделлю А. Д. Соболєвої [9]. Щури групи контролю під час дослідження перебували на звичайному харчовому раціоні. Тварин виводили з експерименту евтаназією шляхом передозування наркозу.

Експерименти виконані з дотриманням вимог Європейської конвенції про захист хребетних тварин, що використовуються для дослідних та інших наукових цілей, (Страсбург, 1986) та Закону України «Про захист тварин від жорстокого поводження» (2006, ст. 26).

Для вивчення мікроскопічної будови використовували методику приготування гістологічних препаратів за Д. С. Саркисовим та Ю. Л. Перовим (1996). Зрізи забарвлювали гематоксиліном та еозином. Вивчення мікропрепаратів здійснювали з використанням світлового мікроскопа Olympus ВН-2 (Японія). Ультрамікроскопічні препарати готували, керуючись рекомендаціями Б. Уіклі (1972). Напівтонкі (1-2 мкм) та ультратонкі (0,05-0,09 мкм) зрізи виготовляли за допомогою скляних ножів на ультрамікротомі УМПТ-ЗМ. Ультраструктурний аналіз проводили у трансмісійному електронному мікроскопі «ПЕМ-100м» (Суми, Україна) з напругою прискорення 75-100 кВ із цифровою камерою Baumer/optronic Typ: CX 05c.

Для дослідження язика з використанням растрового електронного мікроскопа шматочки язика фіксували у 1 \% глутаровому альдегіді, зневоднювали у розчинах етилового спирту зростаючої концентрації (від 50 до 96 ${ }^{\circ}$ ), фіксували на графітових столиках та напилювали вуглецем у вакуумному універсальному пості «ВУП-5», поміщали у растровий електронний мікроскоп із камерою низького вакууму «РЭМ 102», фотографували при збільшенні від $\times 12$ до $\times 10000$ та зберігали на електронному носії.

Морфометричний аналіз здійснювали за допомогою обчислювальної програми «Digimizer». Проводили вивчення таких параметрів: товщина епітелію (TE) та рогового шару (ТРШ), товщина власної пластинки (ТВП), індекс кератинізації (IK), ядерно-цитоплазматичні співвідношення клітин епітелію (ЯЦС), діаметр артеріоли (ДА), діаметр капіляра (ДК), діаметр венули (ДВ), артеріоло-венулярний коефіцієнт (АВК), діаметр м'язового волокна (ДМВ), ширина ендомізія (ШЕ), ширина перимізія (ШП), діаметр міофібрили (ДМФ), площа ядра міосимпласта (ПЯ) та мітохондрії (ПМ). Об'єм мітохондрії (ОМ) та ядра міосимпласта
(ОЯМ) розраховували із використанням формули: $V=4 / 3 \pi a b(a+b) / 2\left(\right.$ мкм $\left.^{3}\right)$, де a - довжина довгої півосі, b - довжина короткої півосі.

Статистичне оброблення усіх одержаних даних проводили з використанням Excel пакета Microsoft Office та програми «GraphPad». Обчислювали середню арифметичну (М), середнє квадратичне відхилення (б), середню помилку середньої величини (m). Достовірність різниці визначали з урахуванням критерію Стьюдента (t), вважаючи за достовірне ймовірність помилки менше $5 \%(p \leq 0,05)$.

Результати й обговорення. Мікроскопічне дослідження слизової оболонки язика щурів, які зазнали внутрішньоклітинного зневоднення протягом 10 днів, показало зменшення розмірів клітин епітелію. Базальні епітеліоцити набували видовженої форми та втрачали своє щільне розміщення один біля одного. Проміжки між ними були розширеними та добре візуалізувалися при великому збільшенні. Клітини шипуватого шару також зменшувалися та набували округлої форми. Спостерігалася втрата їх міжклітинних контактів. Зернистий шар характеризувався передчасним руйнуванням епітеліоцитів та великою кількістю дрібних гранул. Роговий шар мав неоднорідне забарвлення з невеликими просвітленими місцями. У потовщеній підслизовій пластинці відзначалися повнокровні судини мікроциркуляторного русла з набряклими стінками та дещо розширеними просвітами (рис. 1).

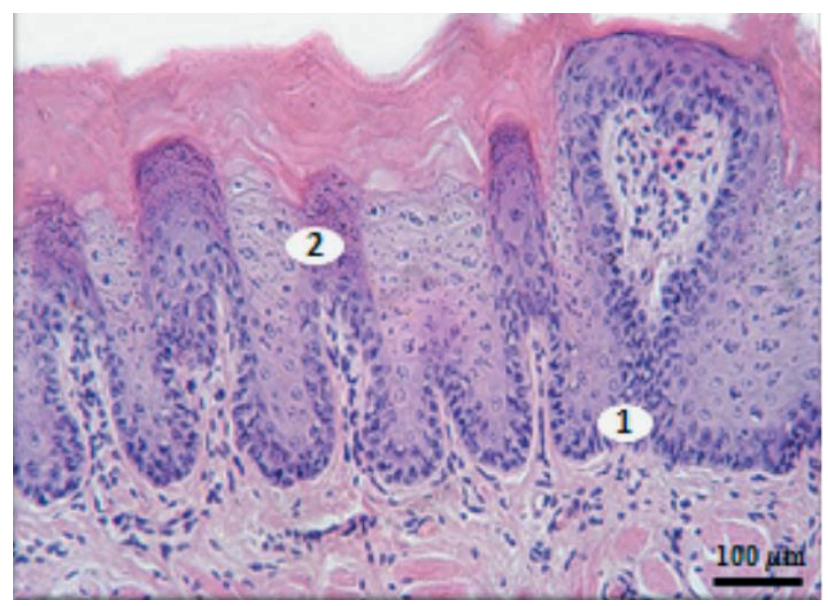

Рис. 1. Слизова оболонка дорсальної поверхні язика щура зрілого віку за умов впливу легкого ступеня внутрішньоклітинного зневоднення. Забарвлення гематоксиліном-еозином: 1 - базальний шар епітелію; 2 - гранули кератогіаліну.

Дослідження морфометричних параметрів слизової оболонки язика виявило збільшення ТЕШ на $3,86 \%$ ( $p=0,0791)$, ТРШ-на 2,85\% ( $p=0,2471)$, а ТВПна $6,46 \%(p=0,2094)$ відповідно, порівняно з контрольною групою тварин. При цьому IК зменшився на $1,08 \%$ ( $p=0,7563)$. ЯЦС епітеліоцитів базального шару 
Огляди літератури, оригінальні дослідження, погляд на проблему

збільшилося на 5,61 \% ( $p=0,0983)$, шипуватого - на Так, відбулося збільшення ДА та ДВ лише на 1,57\% $6,94 \%(p=0,5465)$, зернистого - на 4,38\% ( $p=0,6883) . \quad$ ( $p=0,6075)$ та 3,14\% ( $p=0,0297)$ відповідно, а ДК - на Результати вимірів судинних параметрів виявили- $1,21 \%$ ( $p=0,8276)$, порівняно з інтактною групою. ся статистично недостовірними та незначними. АВК зменшився на 1,58 \% ( $p=0,6804)$ (рис. 2).

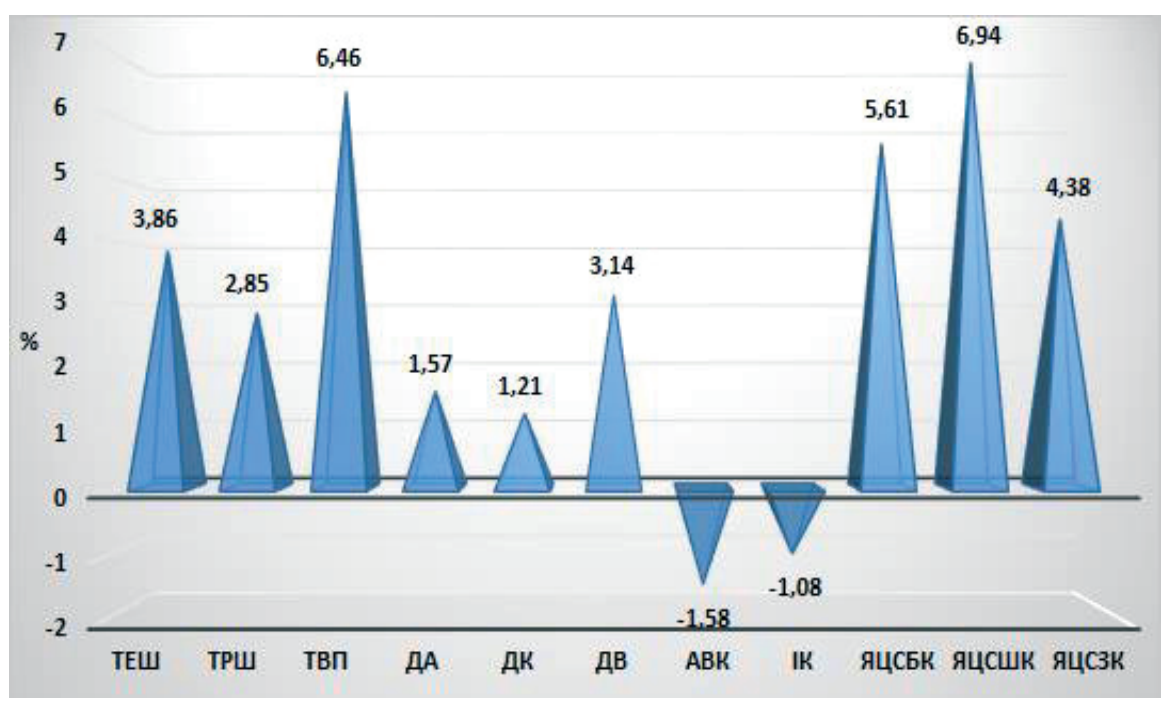

Рис. 2. Зміни морфометричних показників слизової оболонки язика щурів зрілого віку за умов впливу внутрішньоклітинного зневоднення легкого ступеня.

При аналізі електронних мікрофотографій відмічалося розширення сполучнотканинних прошарків між м'язовими волокнами. Місцями спостерігалося локальне стоншання пучків міофібрил, які втрачали своє паралельне розташування та мали хвилястий напрямок. Ядра міосимпластів зменшувалися у розмірах, а ядерце зміщувалося на периферію ядра. Навколоядерний простір просвітлений та розширений. Поперечна посмугованність мала підвищену електронну щільність. Між пучками міофібрил розміщувалися скупчення мітохондрій, які набували округлої форми та мали щільний матрикс. Ядра ендотеліальних клітин містили переважно конденсований хроматин. Ядерна мембрана мала нерівний хвилястий контур, місцями спостерігалися місця її розриву, що може свідчити про початок деструктивних процесів у мікросудинах. Сарколема була розпушена та розширена (рис. 3).

Серед досліджуваних морфометричних параметрів м'яза язика зрілих щурів відзначалося зростання ДМВ, ШЕ та ШП на $5,71 \%(p=0,4379)$, $5,37 \%(p=0,6772)$ та 6,23\% ( $p=0,6057)$ відповідно контрольної групи тварин. При цьому ДМФ зменшився на $2,44 \%(p=0,3653)$, а ОЯМ та ПЯМ - на $4,36 \%(p=0,6036)$ та 5,89\% ( $p=0,6408)$. ОМ та ПМ стали меншими на $2,14 \%(p=0,8493)$ та $1,25 \%$ ( $p=0,9035)$, порівняно з інтактною групою (рис. 4).

Вивчення слизової оболонки язика з використанням растрової електронної мікроскопії виявило набряклі ниткоподібні сосочки, які мали значно розширену основу. Верхівки сосочків на кінчику язика стоншувалися та видовжувалися, а на



Рис. 3. Ультраструктура м'яза язика щура зрілого віку за умов впливу легкого ступеня внутрішньоклітинного зневоднення. 1 - ядро ендотеліоцита; 2 - розпушена сарколема.

спинці - розширювалися та сплющувалися. Валики жолобуватих сосочків зморщувалися, а борозни між ними згладжувалися. Жолобуваті сосочки здіймалися над поверхнею та були на одному рівні з грибоподібними. Тяжі багатожильних сосочків потовщувалися. Роговий шар значними рихлими нашаруваннями укривав листоподібні та багатожильні сосочки (рис. 5).

Висновок. За умов впливу легкого ступеня внутрішньоклітинного зневоднення організму щурів відбувається порушення упорядкованого розподілу клітин епітелію слизової оболонки язика. Епітеліоцити базального та шипуватого шарів 
Огляди літератури, оригінальні дослідження, погляд на проблему

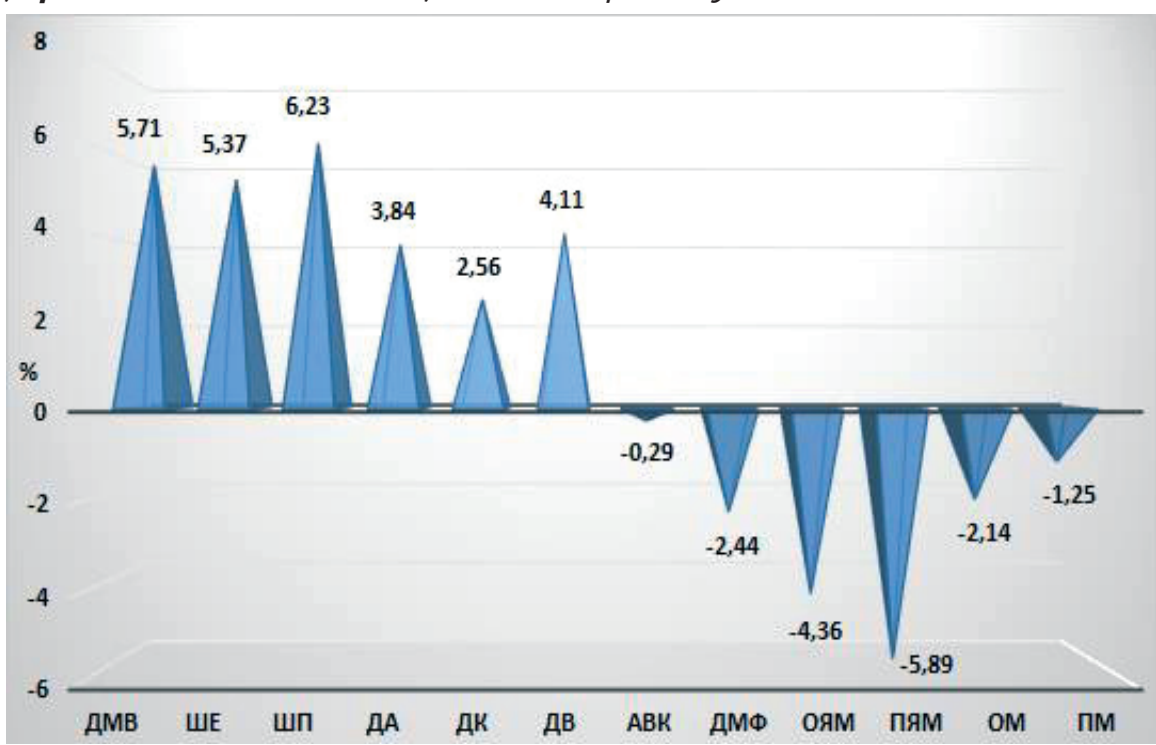

Рис. 4. Зміни морфометричних показників власного м'яза язика щурів зрілого віку за умов впливу внутрішньоклітинного зневоднення легкого ступеня.

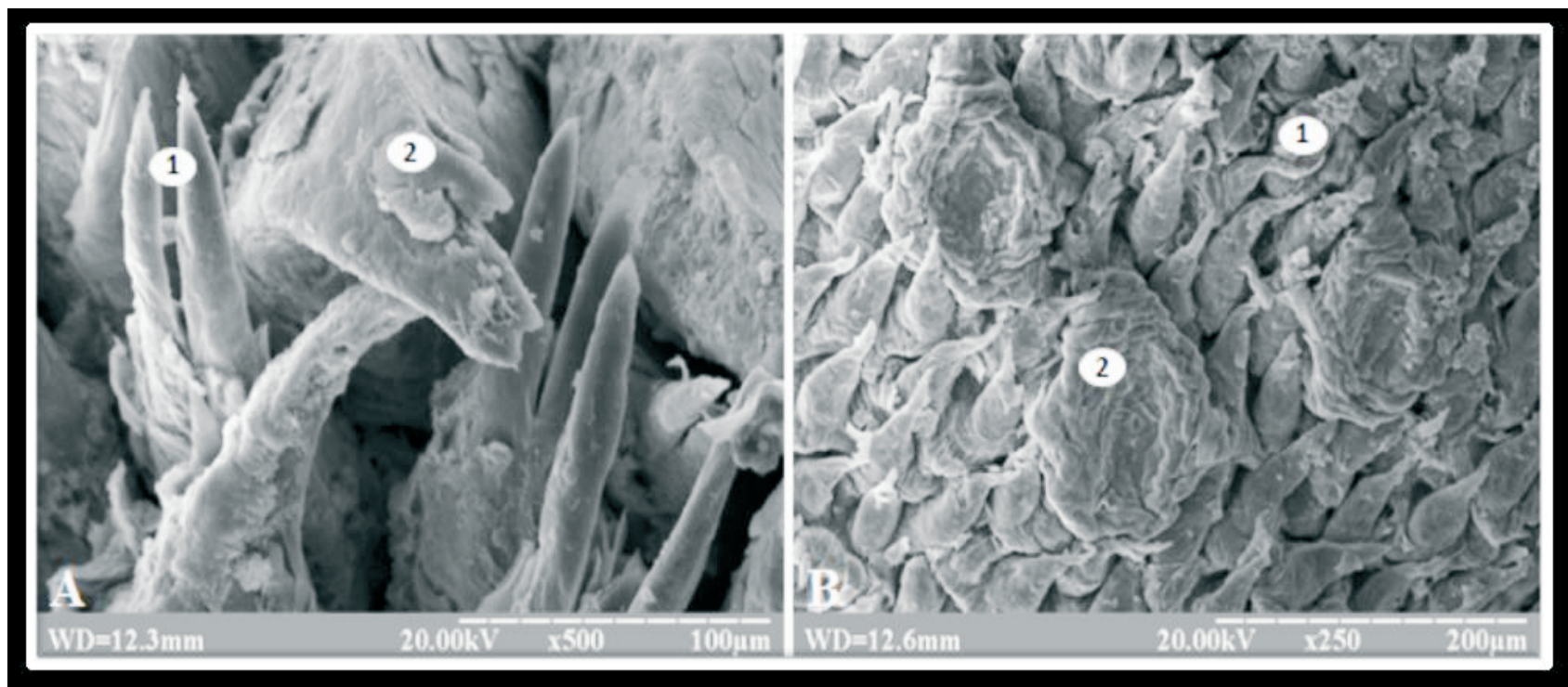

Рис. 5. Слизова оболонка дорсальної поверхні язика щура зрілого віку за умов впливу внутрішньоклітиного зневоднення легкого ступеня: А: 1 - набряклі багатожильні сосочки; 2 - рогові нашарування; В: 1 - ниткоподібні сосочки; 2 - жолобуватий сосочок.

зменшуються у розмірах, втрачаючи між собою контакти. Збільшуються міжклітинні проміжки. Відбувається передчасне руйнування зернистих клітин та набряк власної пластинки. Пучки міофібрил локально стоншуються, місцями втрачають паралельне розташування, набувають хвилястого напрямку за рахунок набряку сполучнотканинних прошарків. Судини мікроциркуляторного русла стають повнокровними, стінки набряклими, а їх просвіти розширеними.

Перспективи подальших досліджень. Отримати дані про можливість корекції структурних змін у язиці щурів, які виникли за умов впливу гіпертонічної дегідратації. 
Огляди літератури, оригінальні дослідження, погляд на проблему

\section{ЛІТЕРАТУРА}

1. Попутников Д. М. Нарушения водно-электролитного обмена (патофизиологические аспекты) / Д. М. Попутников, Е. В. Меленчук, Ф. И. Висмонт. Минск : БГМУ, 2011. - 32 с.

2. Зайко Н. Н. Патологическая физиология / Н. Н. Зайко, Ю. В. Быць; под ред. Н. Н. Зайко. - М. : МЕДпресс-информ, 2007. - 640 с.

3. Дергунов А. В. Нарушения электролитного о6мена в тканях крыс при дегидратации и гипергидратации / А. В. Дергунов, В. М. Хмара, Г. П. Гусев // Актуальные проблемы транспортной медицины. - 2012. № 2 (28). - C. 139-143.

4. Apostu M. A strategy for maintaining fluid and electrolyte balance in aerobic effort / M. Apostu // Procedia Social and Behavioral Sciences.-2014. - № 117.-P. 323-328.

5. Банченко Г. В. Язык - "зеркало" организма : клиническое руководство для врачей / Г. В. Банченко,
Ю. М. Максимовский, В. М. Гринин. - М. : Бизнес центр "Стоматология", 2000. - 406 с.

6. Латышева С. В. Фундаментальные основы диагностики заболеваний слизистой оболочки полости рта : учебно-метод. пособие / С. В. Латышева. - Минск, 2004. -60 c.

7. Латышева С. В. Болезни языка (диагностика, методы лечения) : учебно-метод. пособие / С. В. Латышева, Л. В. Белясова, В. И. Урбанович. - Минск, 2004. - 2 c.

8. Traumatic atrophic glossitis (Riga-Fede disease) as a symptom of familial dysautonomia - the Riley-Day syndrome / S. Dluholucky // Cesk. Pediatr. - 1991. Vol. 46. - P. 347-348.

9. Соболева А. Д. Реакция клеток и тканей на обезвоживание / А. Д. Соболева. - Новосибирск : Наука, 1975. -64 c.

\title{
REFERENCES
}

1. Poputnikov, D. M., Melenchuk, E.V. \& Vismont, F.I. (2011). Narusheniya vodno-elektrolitnogo obmena (patofiziologicheskie aspekty) [Disorders of water-electrolyte metabolism (pathophysiological aspects)]. Minsk: BHMU [in Russian].

2. Zayko, N.N. \& Byts, Yu.V. (2007). Patologicheskaya fiziologiya [Pathological physiology]. Moscow: MED-pressinform [in Russian]

3. Dergunov, A.V., Khmara, V.M. \& Gusev, G.P. (2012). Narusheniya elektrolitnogo obmena v tkanyakh krys pry degidratatsyy i gipergidratatsyy [Disorders of electrolyte metabolism in tissues of rats with dehydration and hyperhydration]. Aktualnye problemy transportnoy meditsyny - Actual Issues of Transport Medicine, 2 (28), 139-143 [in Russian].

4. Apostu, M. (2014). A strategy for maintaining fluid and electrolyte balance in aerobic effort. Procedia-Social and Behavioral Sciences, (117), 323-328.

5. Banchenko, G.V., Maksimovskiy, Yu.M. \& Grynin, V.M. (2000). Yazyk - «zerkalo» organizma Klinicheskoe ruko-

vodstvo dlya vrachey [Language - the "mirror" of the body: a clinical guide for doctors]. Moscow: "Biznes tsentr "Stomatologiya" [in Russian].

6. Latysheva, S.V. (2004). Fundamentalnye osnovy diagnostiky zabolevaniy slizystoy obolochky polosti rta: uchebno-metod. posobie [Fundamentals of diagnosis of diseases of the oral mucosa: guidance manual]. Minsk [in Russian].

7. Latysheva, S.V., Belyasova, L.V. \& Urbanovich, V.I. (2004). Bolezny yazyka (diagnostika, metody lecheniya): uchebno-metod. posobie [Diseases of the tongue (diagnosis, treatment methods): guidance manual]. Minsk [in Russian].

8. Dluholucky, S. (1991) Traumatic atrophic glossitis (Riga-Fede disease) as a symptom of familial dysautonomia - the Riley-Day syndrome. Cesk. Pediatr., 46, 347-348.

9. Soboleva, A.D. (1975). Reaktsyya kletok i tkaney na obezvozhyvanie [Response of cells and tissues to dehydration]. Novosibirsk: Nauka [in Russian].

\section{ОСОБЕННОСТИ МОРФОГЕНЕЗА ЯЗЫКА КРЫС ПРИ НАРУШЕНИИ ВОДНО-ЭЛЕКТРОЛИТНОГО БАЛАНСА ОРГАНИЗМА}

\author{
๔Л. Н. Давыдова, Г. Ф. Ткач, С. Н. Герман, А. Н. Буштрук, Е. С. Максимова \\ Сумской государственный медицинский университет
}

РЕЗЮМЕ. Обезвоживание организма является одной из причин функциональных заболеваний слизистой оболочки полости рта. Изучение изменений языка на клеточном и тканевом уровнях в условиях воздействия гипертонической дегидратации организма способствует получению новых знаний для научного обоснования целенаправленной профилактики и медикаментозной терапии нарушений языка у человека и животных.

Целью исследования было изучить морфологические особенности языка крыс в условиях воздействия внутриклеточной дегидратации организма.

Материал и методы. Для эксперимента были использованы 20 белых лабораторных крыс. Исследование препаратов проводили с использованием светового микроскопа Olympus BH-2 (Япония), электронного трансмиссионного микроскопа «ПЭМ-100м» (Сумы, Украина) и растрового электронного микроскопа «РЭМ-106» (Сумы, Украина).

Результаты. Установлено, что в условиях воздействия на организм крыс внутриклеточного обезвоживания легкой степени происходит нарушение упорядоченного распределения клеток эпителия слизистой оболочки языка. Эпителиоциты базального и шиповатого слоев уменьшаются в размерах, теряя между собой контакты и 
Огляди літератури, оригінальні дослідження, погляд на проблему

увеличивая промежутки. Происходит преждевременное разрушение зернистых клеток и отек собственной пластинки. Толщина эпителия увеличивается на 3,86 \% (p=0,0791), а собственной пластинки - на 6,46 \% ( $p=0,2094)$. Пучки миофибрилл локально истончаются, местами теряют параллельное расположение, приобретают волнистое направление за счет отека соединительнотканных прослоек. Ширина эндомизия и перимизия увеличивается на 5,37\% ( $=0,6772)$ и 6,23\% ( $=0,6057)$. Сосуды микроциркуляторного русла становятся полнокровными, стенки отечными, а их просветы расширенными.

КЛЮчЕВЫЕ СЛОВА: слизистая оболочка языка; внутриклеточная дегидратация; ультраструктура.

\section{PARTICULARITIES OF THE MORPHOGENESIS OF RAT'S TONGUE UNDER CONDITIONS OF WATER-ELECTROLYTE DISBALANCE OF AN ORGANISM}

\section{@L. M. Davydova, G. F. Tkach, S. M. German, A. M. Bushtruk, O. S. Maksymova Sumy State Medical University}

SUMMARY. The organism dehydration is one reason of the functional diseases of mucous membrane of oral cavity. The tongue changes study at the cellular and tissue levels under the influence of organism hypertonic dehydration provides obtaining the new knowledge for scientific justification of targeted prevention and drug therapy tongue diseases in humans and animals.

The aim of the study was to learn the morphological features of rat's tongue under the influence of organism hypertonic dehydration.

Materials and Methods. The experiment was performed on 20 white laboratory rats. The specimens were analyzed using the light microscope "OLYMPUS» (Japan), scanning and transmission electron microscope ("SEM-125K» and "SEM106A») (Sumy, Ukraine).

Results. It was found that the disruption of ordered cells distribution of epithelium of tongue mucous membrane occurs under influence of mild cellular dehydration. The epithelial cells of basal layer and stratum spinosum are decreased in size, their contacts are lost and the space between them is increased. The premature of the granulosa cells disruption and the edema of lamina propria are occurred. The epithelial thickness is increased by $3.86 \%(p=0.0791)$ and the lamina propria thickness is increased by $6.46 \%(p=0.2094)$. The bundles of myofibrils are locally become thin and are lost the parallel arrangement, and are get the wavy circuit due to the compression by swollen connective tissue interlayers. The width of endomysium and perimysium is increased by $5.37 \%(p=0.6772)$ and $6.23 \%(p=0.6057)$ accordingly. The microcirculatory bloodstream vessels became plethoric, their walls were edematous and their lumens were enlarged.

KEY WORDS: the mucous membrane of tongue; hypertonic dehydration; ultrastructure. 